\title{
Strategi Pemberdayaan Masyarakat Miskin Berbasis Potensi Lokal di Kabupaten KEDIRI
}

\author{
Lilik Aniyati $^{1}$ \\ Alfiah $^{2}$ \\ Program Studi Manajemen \\ Sekolah Tinggi Ilmu Ekonomi Kertanegara Malang \\ Alfiah.said@gmail.com
}

\begin{abstract}
Abstrak : Tujuan dari penelitian Strategi Pemberdayaan Masyarakat Miskin Berbasis Potensi Lokal di Kabupaten Kediri adalah untuk: 1) Melakukan identifikasi tentang karakteristik permasalahan masyarakat miskin; 2) Melakukan identifikasi ragam potensi lokal yang ada; 3) Melakukan evaluasi terhadap pelaksanaan program-program penanggulangan kemiskinan; 4) Menyusun strategi pemberdayaan masyarakat miskin berdasarkan ragam potensi setempat yang ada di wilayah Kabupaten Kediri. Prioritas yang utama dari kabupaten kediri adalah pada sektor Pertanian, Perkebunan, Peternakan dan Perikanan kemudian pada sektor berikutnya adalah Perdagangan, Hotel \& Restoran dan sektor prioritas selanjutnya adalah bidang industri dan Jasajasa. Sentra penghasil mangga podang di Kabupaten Kediri terdapat di lima kecamatan yang melingkari gunung Wilis yaitu Kecamatan Banyakan, Tarokan, Grogol, Mojo, dan Semen. Jumlah mangga Podang terbesar berada di Kecamatan Banyakan dan Tarokan dengan jumlah kurang lebih 15 ribu pohon. Rata-rata hasil panen perpohon 20-40 kg maka potensi total panen mangga podang bisa mencapai 600 ton permusim. Kelompok Wanita Tani 'Budidaya' yang berlokasi di dusun Sumberbendo, telah mendirikan industri rumah tangga olahan mangga podang bekerjasama dengan JICA (Japan International Cooperation Agency: Lembaga pendanaan dari Pemerintah Jepang), Dinas Pertanian Kabupaten Kediri, dan Universitas Brawijaya. Kelompok tani Sumber Mulyo yang berlokasi di dusun Kali Gayam, bekerja sama dengan LSM Internasioanal REI (Resource Exchange International) berhasil melahirkan produk manisan mangga podang yang telah menembus pasar luar negeri. Tujuan utama pengembangan olahan mangga podang adalah meningkatkan pendapatan petani mangga podang dikarenakan harga produk mangga podang saat itu sangat rendah terutama pada saat panen raya sehingga perlu terobosan guna mendapatkan nilai tambah mangga podang. Setelah banyak produk olahan manga podang di pasaran, maka harga buah segar mangga podang pun ikut naik. Hal ini dikarenakan banyak buah mangga podang yang terserap sebagai bahan baku olahan mangga podang. Kalau dulu mangga podang hanya bisa dinikmati pada saat musim mangga, maka sekarang bisa dinikmati sepanjang tahun melalui olahan mangga podang. Dusun Bulur, Kecamatan Kandat, merupakan salah satu dusun yang terkenal sebagai sentra usaha tahu dengan kualitas terbaik. Sebagai salah satu industri rumahan, usaha ini masuk dalam dalam kategori usaha kecil menengah yang tergabung dalam Kelompok Usaha Bersama (KUBE) binaan Dinas Sosial Kabupaten Kediri. Cara pembuatan tahu pun masih dengan cara tradisional,sehingga peran individu atau dalam hal ini para pekerja sangatlah besar dalam proses pembuatanya.
\end{abstract}

Keyword: Strategi Pemberdayaan, Masyarakat Miskin, Potensi Lokal 


\section{Pendahuluan}

Kemiskinan merupakan masalah sosial ekonomi negeri ini sejak sebelum kemerdekaan sampai pasca kemerdekaan. Pada masa Orde Baru saja walaupun pertumbuhan ekonomi cukup tinggi, yaitu rata-rata sebesar 7,5 persen selama tahun 1970-1996, namun penduduk miskin di Indonesia tetap tinggi. Berdasarkan data Badan Pusat Statistik (BPS), persentase penduduk miskin di Indonesia tahun 1996 masih sangat tinggi, yaitu sebesar 17,5 persen atau 34,5 juta orang. Hal ini bertolak belakang dengan pandangan banyak ekonom yang menyatakan bahwa pertumbuhan ekonomi yang tinggi dapat meningkatkan pendapatan masyarakat dan pada akhirnya mengurangi penduduk miskin. Perhatian pemerintah terhadap pengentasan kemiskinan pada pemerintahan reformasi terlihat lebih besar lagi setelah terjadinya krisis ekonomi pada pertengahan tahun 1997. Meskipun demikian, berdasarkan penghitungan BPS, persentase penduduk miskin di Indonesia sampai tahun 2003 masih tetap tinggi, yaitu sebesar 17,4 persen, dengan jumlah penduduk yang lebih besar, yaitu 37,4 juta orang.

Perencanaan, penentuan sasaran, dan kriteria miskin serta pengaturan teknis pelaksanaan program penanggulangan kemiskinan yang dilakukan selama ini oleh pemerintah atau instansi terkait seringkali bersifat terpusat (top-down), sehingga program tersebut tidak sesuai dengan kebutuhan masyarakat atau daerah tertentu. Sehingga banyak program penanggulangan kemiskinan yang menempatkan masyarakat sebagai obyek, akibatnya masyarakat kurang berpartisipasi secara aktif dalam menggali potensi dirinya dan lingkungannya untuk keluar dari kemiskinan. Selain itu programprogram yang dilaksanakan cenderung bersifat sektoral yang sering kali mengakibatan adanya semangat ego-sektoral dan saling tumpang tindih. Keadaan ini lebih dipersulit karena umumnya tiap departemen atau instansi mempunyai definisi dan kriteria sendiri tentang kemiskinan. Akibatnya kemiskinan cenderung dipahami secara parsial, dan penanggulangannya cenderung bersifat sektoral. Hal inilah yang menyebabkan sulitnya menjaga kontinuitas program dan cenderung membuat program baru, dimana program baru tersebut bukan merupakan kelanjutan program lama.

Berangkat dari kegagalan dari program penanggulangan kemiskinan sebelumnya, maka diperlukan strategi atau model program penanggulangan kemiskinan yang pada prinsipnya menjadikan masyarakat miskin sebagai subyek. Untuk itu diperlukan model yang bisa: Pertama, mendidik masyarakat miskin untuk terus menerus menemukenali potensi yang dimiliki baik individu, keluarga, maupun lingkungan (keterampilan, material, dan sumber daya alam) sebagai modal dasar untuk meningkatkan kesejahteraan hidupnya. Sehingga dengan mengenali potensi tersebut, akan mendorong tumbuhnya rasa percaya diri mereka akan kemampuannya untuk lepas dari belenggu kemiskinan. Kedua, model tersebut juga harus mampu menyadarkan bahwa tidak akan ada seseorang/lingkungan yang dapat keluar dari kemiskinan, melainkan atas usaha orang/keluarga/lingkungan itu sendiri serta memberikan pemahaman bahwa masalah penanggulangan kemiskinan merupakan tugas dan tanggungjawab bersama pemerintah dan masyarakat. Sampai saat ini telah banyak hasil studi maupun program yang bertujuan untuk mengatasi masalah kemiskinan di Indonesia. Meskipun demikian fenomena kemiskinan di Indonesia realitasnya belum bisa dilepaskan secara signifikan dari kehidupan masyarakat di Indonesia.

Berdasarkan laporan Tim Nasional Percepatan Penanggulangan Kemiskinan (TNP2K) tentang indikator kesejahteraan daerah Propinsi Jawa Timur tahun 2011, persentase tingkat kemiskinan Propinsi Jawa Timur sebesar $15,52 \%$ dan berada di urutan 15 dari 33 Propinsi, jika dibandingkan dengan angka porsentase tingkat kemiskinan nasional (13,33\%), maka tingkat kemiskinan Propinsi Jawa Timur masih 
berada di atas angka porsentase nasional. Sedangkan berdasarkan tingkat kemiskinan kab/kota di Jawa Timur, Kabupaten Kediri menempati urutan 16 dari 38 kab/kota di Jawa Timur atau 15,52\%. Jika dibandingkan dengan tingkat kemiskinan Propinsi Jawa Timur, tingkat kemiskinan Kabupaten Kediri berada dibawah sedikit tingkat kemiskinan Jawa Timur, namun jika dibandingkan dengan porsentase tingkat kemiskinan nasional, porsentase tingkat kemiskinan Kabupaten Kediri masih berada di atas porsentase tingkat kemiskinan nasional.

Mencermati berbagai pelaksanaan program penanggulangan kemiskinan di Indonesia, ada beberapa evaluasi terhadap beberapa kelemahan dalam rangka pelaksanaan program penanggulangan kemiskinan diantaranya adalah (1) programprogram penanggulangan kemiskinan di daerah masih bersifat parsial, belum terpadu dan tidak komfrehensif, (2) belum tersedianya instrument upaya penanggulangan kemiskinan yang spesifik sesuai dengan keragaman dimensi permasalahan kemiskinan di setiap daerah, (3) berbagai upaya yang semula diproyeksikan dapat mengatasi masalah kemiskinan, pada kenyataannya justru melahirkan permasalahan baru yang pada gilirannya berakibat menurunnya kepercayaan publik terhadap pemerintah dalam mengatasi masalah kemiskinan. Berdasarkan kondisi existing penanggulangan kemiskinan di daerah serta adanya pergeseran paradigma dalam pembangunan nasional dari top down menjadi bottom up, maka penting untuk merumuskan strategi pemberdayaan masyarakat yang sesuai dengan ragam potensi lokal di setiap wilayah atau spasial di daerah. Berpijak pada latar belakang tersebut, memandang penting untuk melakukan penelitian strategi pemberdayaan masyarakat miskin berbasis potensi lokal di Kabupaten Kediri.

\section{Metode}

\section{A. Kerangka Konseptual}

Kemiskinan merupakan masalah multidimensi yang memerlukan penanganan secara menyeluruh dan bersama dengan mengedepankan penghormatan, perlindungan, dan pemenuhan hak dasar manusia. Kemiskinan terjadi bukan semata karena kurangnya pendapatan, tetapi karena tidak terpenuhinya hak-hak dasar masyarakat miskin untuk mempertahankan dan memenuhi kehidupan yang bermartabat sebagai bagian dari hak manusia yang paling asasi. Strategi Penanggulangan Kemiskinan memandang bahwa pendekatan hak dasar manusia menjadi titik tolak paling esensial untuk menghormati dan melindungi setiap warganegara yang karena kelahirannya ataupun proses naturalisasi agar terpenuhi martabatnya sebagai bagian dari perikemanusiaan dan perikeadilan

Penanggulangan kemiskinan secara menyeluruh tidak dapat hanya dilakukan oleh pemerintah pusat, tetapi juga harus dilakukan di tingkat daerah. Seiring dengan diberlakukannya otonomi daerah, kota/kabupaten menjadi pelaku strategis untuk langsung melakukan upaya penanggulangan kemiskinan di wilayahnya. Pemerintah daerah, lebih mengenal secara dekat karakteristik dan tingkat kemiskinan di wilayahnya, sehingga untuk menyusun strategi, kebijakan dan program yang bersifat khusus tidak dapat mengandalkan strategi dan kebijakan di tingkat pusat.

Masalah kemiskinan merupakan problem yang dihadapai oleh masyarakat dunia, terutama negera-negara dunia ketiga, tak terkecuali Indonesia. Berbagai upaya telah dilakukan oleh pemerintah, baik pusat maupun daerah untuk menyelesaikan problem ini. Pemerintah Kabupaten Kediri, dalam hal ini Badan Perencanaan Pembangunan Daerah, berusaha merumuskan suatu strategi pemberdayaan bagi masyarakat miskin di Kabupaten Kediri dengan melihat basis potensi lokal yang ada. Untuk melakukan itu 
perlu terlebih dahulu dilakukan kajian dan penelitan. Penelitian tersebut, selain dengan menggali data secara langsung di lapangan, mengkaji hasil-hasil kajian sebelumnya.

B. Jenis Data

Dilihat dari sumbernya, data yang digunakan dalam penelitian ini ada dua jenis yaitu data sekunder dan data primer.

a.

Data Sekunder

Data ini merupakan data yang telah dikumpulkan oleh pihak lain. Adapun data sekunder yang akan digunakan dalam penelitian ini diantaranya seperti; Jumlah penduduk, luas desa, topografi desa, monografi desa, letak geografi desa dan data penduduk misikin. Data penduduk miskin Kabupaten Kediri yang akan dianalisis dalam penelitian ini adalah data yang bersumber dari hasil akhir Pendataan Program Perlindungan Sosial (PPLS).

b. Data Primer

Data ini merupakan data yang diperoleh langsung dari obyek penelitian. Adapun data primer yang digunakan dalam penelitian ini diantaranya seperti; data yang digunakan untuk mengukur indikator kelembagaan, indikator tipologi/penyebab kemisikinan, indikator sumberdaya dan potensi ekonomi, dan lain-lain.

C. Teknik Pengumpulan Data

Metode yang digunakan dalam pengumpulan informasi dan data yang digunakan dalam penelitian ini adalah Participatory Rural Appraisal (PRA), meliputi:

a. Wawancara, yaitu metode pengumpulan data dengan wawancara secara mendalam dengan key-person (formal dan informal leaders), untuk mengidentifikasi kebutuhan (needs) masyarakat.

b. Dokumentasi, yaitu metode pengumpulan data sekunder yang dimiliki oleh responden, lembaga ekonomi dan sosial, maupun instansi teknis terkait.

c. Observasi (pengamatan) dan survei lapang

Dalam hal meyakinkan data dan informasi yang diperoleh dari responden, peneliti mengadakan pengamatan dan survei lapang secara langsung terhadap obyek yang diamati, mendengar serta mencatat hasil temuan lapang.

d. Pengumpulan Data Sekunder

Selain dukungan data primer yang menjadi sumber data utama, penelitian ini juga menggunakan data sekunder yang diperoleh dari dokumen-dokumen serta catatan-catatan yang berhubungan dengan masalah yang diteliti. Dokumen yang dimaksud adalah jumlah keluarga miskin yang diperoleh dari Badan Perencanaan Kabupaten Kediri yang menjadi sampel penelitian dan statistik kecamatan dari kecamatan yang diterbitkan oleh Kantor Statistik.

e. Focus Group Discussion (Diskusi Kelompok)

Peneliti melaksanakan diskusi dengan obyek penelitian ketika peneltian lapang akan dilakukan. Kegiatan ini pertama dilakukan adalah dimaksudkan untuk mensosialisasikan pelaksanaan pengumpulan data (sebagai kegiatan penting penelitian ini) kepada para sekretaris kecamatan dan seluruh sekretaris desa/kelurahan yang diperkirakan menjadi sasaran dari kegiatan penelitian lapang. Berbagai informasi yang disampaikan dalam kegiatan sosialisasi ini, antara lain 
meliputi: pentingnya dilaksanakan kegiatan inventarisasi dan pemetaan kemiskinan di Kabupaten Kediri, proses pengumpulan data, dan hasil akhir yang dihasilkan kegiatan ini. Melalui kegiatan ini dicapai jalinan suatu kebersamaan antara peneliti dengan calon responden (subyek yang diteliti), sehingga dapat diperoleh data yang optimal

Diskusi kelompok kedua dilakukan pada saat menjelang kegiatan ini berakhir. Diskusi ini dilakukan dengan stakeholders tingkat kabupaten, dimaksudkan untuk mengoptimalkan hasil temuan lapangan. Dikusi kelompok ini diarahkan kepada upaya-upaya mengklarifikasi hasil temuan lapangan, mendapatkan koreksi dan masukan, serta kesepakatan tentang hasil akhir kegiatan ini.

\section{Alat Analisis}

Studi ini menggunakan beberapa alat analisis untuk menjawab tujuan dan menghasilkan output sesuai sasaran/target. Alat analisis tersebut meliputi: 1) Locationt Quatient (LQ), 2) Kontribusi sektoral, 3) Analisis Sarana dan Prasarana, dan 4) Diskriptif kualitatif.

a. Locationt Quatient (LQ)

Teknik analisis ini digunakan untuk menentukan kategori suatu sektor termasuk dalam sektor basis atau bukan basis. Formulasi dari teknik analisis tersebut adalah (Azis, 1994):

$$
\begin{gathered}
V A_{i}^{J_{i}} / V A^{I_{i}} \\
L Q_{i}^{J}= \\
\mathrm{PDRB} B^{J} P D R B^{I}
\end{gathered}
$$

Keterangan:

$$
\begin{array}{lr}
L Q_{i}^{J} & =\text { Location Quatient sektor i di daerah J } \\
V A^{J} & =\text { Nilai tambah sektor i di daerah J } \\
V A_{i}^{I} & =\text { Nilai tambah sektor i di tingkat kabupaten } \\
P D R B^{J} & =\text { Produk Domestik Regional Bruto di daerah J } \\
P D R B^{I} & =\text { Produk Domestik Regional Bruto Kabupaten }
\end{array}
$$

Dari hasil perhitungan yang diperoleh, dapat diartikan dalam dua kategori, yaitu:

1. Bila nilai LQ lebih kecil atau sama dengan 1, menunjukkan bahwa sektor tersebut bukan sektor basis.

2. Bila nialai LQ lebih besar dari 1, menunjukkan bahwa sektor tersebut adalah sektor basis.

b. Kontribusi Sektoral

Kontribusi sektor ekonomi dapat menunjukkan besar kecilnya masing-masing sektor terhadap perekonomian daerah. Sektor ekonomi disini dikelompokkan menjadi sembilan, yaitu sektor: 1) Pertanian, 2) Pertambangan, 3) Industri pengolahan, 4) Listrik, gas, air bersih, 5) Kontruksi, 6) Perdagangan, Hotel dan Restoran 7) Pengangkutan dan Komunikasi, 7) Keuangan, Persewaan dan Jasa Perusahaan, dan 9) Jasa-jasa. Penghitungan kontribusi sektoral dapat dirumuskan sebagai berikut: 


$$
\mathrm{PS}_{\mathrm{i}}=\frac{\text { PDRBi }}{\text { PDRBi }} \times 100 \%
$$

Dimana:

- Psi : proporsi / kontribusi sektor i terhadap PDRB

- PDRB $_{i} \quad$ : jumlah PDRB seluruh sektor

\section{c. Analisis Sarana dan Prasarana}

Tujuan analisis ini yaitu untuk mengukur daya dukung sarana dan prasarana yang dibutuhkan oleh kawasan rencana. Dari sini akan dibandingkan lokasi yang satu dengan yang lainnya terkait daya dukung sarana dan prasarananya. Untuk memenuhi tujuan, dalam perencanaan ini akan menggunakan analisis indek sentralitas (centrality indek analysis / CI).

Menurut Bratakusumah dan Riyadi (2005), alat analisis indek sentralitas dapat digunakan untuk mengetahui struktur pusat-pusat pelayanan yang ada disuatu wilayah. Pusat-pusat pelayanan ini dalam bentuk fisik yaitu sarana dan prasarana yang ada disuatu wilayah. Langkah-langkah untuk menghitung indek ini, yaitu:

1) Memasukkan nama-nama wilayah (kecamatan) yang ada di Kabupaten Kediri ke dalam matrik.

2) Memasukkan ke dalam matrik jumlah populasi yang ada dimasing-masing kecamatan.

3) Memasukkan ke dalam matrik yaitu jumlah masing-masing sarana prasarana yang terdapat pada masing-masing kecamatan.

4) Menjumlahkan total sarana prasarana sejenis diseluruh kecamatan.

5) Total centrality (TC) tiap jenis sarana prasarana 100.

6) Menghitung nilai bobot dengan rumus: TC dibagi jumlah sarana prasarana Xi.

7) Menjumlahkan seluruh sarana prasarana $X i$ di satu kecamatan tertentu.

8) Menghitung CI dengan rumus: jumlah nilai bobot seluruh sarana kecamatan $j$ di bagi jumlah sarana yang terisi.

9) Menyimpulkan

d. Analisis Kualitatif

Selain menggunakan metode analisis data yang bersifat kuantitatif, dalam penelitian ini juga menggunakan alat analisis yang bersifat kualitatif yaitu berupa keterangan-keterangan atau pendapat-pendapat yang diutarakan oleh para ahliahli, pihak-pihat terkait melalui focus group discussion (FGD) dan, literaturliteratur dan hasil-hasil penelitian yang dilakukan oleh peneliti terdahulu yang mempunyai keterkaitan dengan kebutuhan-kebutuhan orang miskin dan penyebab kemiskinan.

\section{Hasil Penelitian dan Pembahasan}

A. Model Pemberdayaan Masyarakat Miskin Pendekatan Kelompok

Perluasan program pembangunan berbasis pada keterlibatan seluruh komponen atau potensi lokal setempat merupakan model pembangunan berkelanjutan. Artinya, perluasan program pembangunan berarti memberikan penguatan peran masyarakat setempat untuk lebih mampu mengoptimalkan seluruh sumber daya yang ada secara produktif, kreatif dan berwawasan ke depan untuk pengentasan kemiskinan dan rawan pangan secara mandiri. 
Berdasarkan individu dari karakteristik masyarakat miskin maka secara pribadi perlu pendekatan pemberdayaan yang bebasis pada potensi individu untuk ditingkatkan menjadi pribadi yang lebih maksimal, berikut ini adalah model pendekatan berdasarkan karakter masyarakat miskin

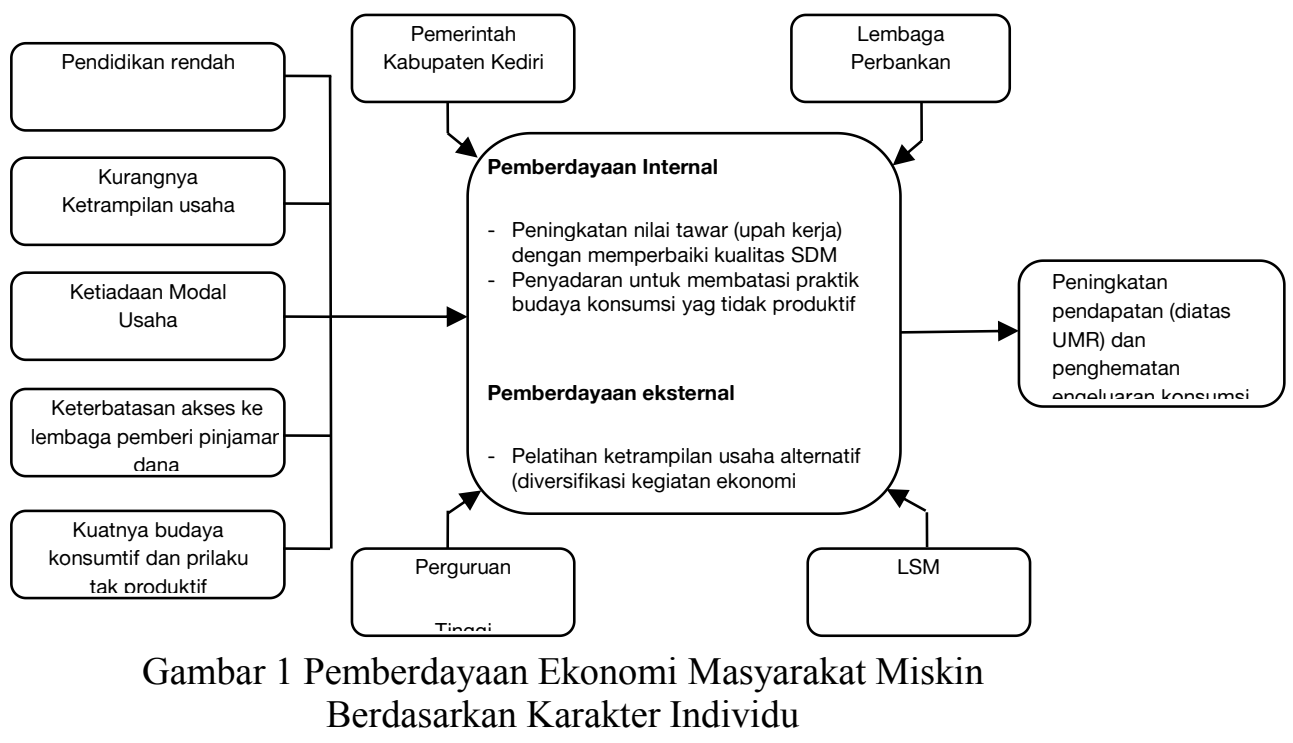

1. Pemberdayaan Masyarakat Miskin Melalui Kelompok Produktif

Salah satu model pemberdayaan masyarakat miskin adalah melalui olahan buah mangga podang. Mangga podang ternyata memiliki kekhasan bila dibandingkan dengan buah mangga jenis lain baik dari segi rasa ataupun warnanya. Warna kulitnya kuning dengan sedikit bintik merah didekat pangkal dahannya, membawa daya tarik tersendiri bila dipandang. Aromanya khas mengundang selera segar apabila didekati. Rasanya manis walau tanpa gula. Benar-benar memenuhi syarat buah unggulan yang layak untuk dijadikan oleh-oleh khas Kediri.

Sentra penghasil mangga podang di Kabupaten Kediri terdapat di lima kecamatan yang melingkari gunung Wilis yaitu Kecamatan Banyakan, Tarokan, Grogol, Mojo, dan Semen. Jumlah mangga Podang terbesar berada di Kecamatan Banyakan dan Tarokan dengan jumlah kurang lebih 15 ribu pohon. Rata-rata hasil panen perpohon $20-40 \mathrm{~kg}$ maka potensi total panen mangga podang bisa mencapai 600 ton permusim.

Potensi mangga podang yang berlimpah ini memerlukan pemikiran yang kreatif untuk memberikan nilai tambah baik itu nilai tambah ekonomi maupun sosial. Nilai tambah ekonomi dapat diwujudkan melalui olahan mangga podang menjadi produk yang tahan lama sehingga persebarannya bisa lebih luas dan tentunya juga memiliki nilai jual yang lebih tingi. Sedangkan nilai tambah sosial adalah dampak dari nilai tambah ekonomi, misalnya munculnya industri rumah tangga olahan mangga podang, bisa membuka lapangan pekerjaan baru bagi warga sekitar yang rata-rata mengandalkan hidup dari pertanian di lahan kering sehingga muncul alternatif ekonomi baru yang bisa mendukung perekonomian desa.

Pemikiran kreatif tersebut tampaknya sudah disadari oleh dua kelompok tani di desa Tiron - Kecamatan Banyakan yaitu Kelompok Wanita Tani 'Budidaya' di bawah pimpinan Bu Luluk dan Kelompok tani 'Sumber Mulyo' yang diketuai Pak Jemu. Dua orang inilah yang memiliki semangat membawa perubahan di 
dusunnya masing-masing. Memberi inspirasi bagi warga sekitarnya untuk tidak takluk dengan kerasnya alam di lereng gunung Wilis.

Pertama, Kelompok Wanita Tani 'Budidaya' yang berlokasi di dusun Sumberbendo ini, telah mendirikan industri rumah tangga olahan mangga podang bekerjasama dengan JICA (Japan International Cooperation Agency : Lembaga pendanaan dari Pemerintah Jepang), Dinas Pertanian Kabupaten Kediri, dan Universitas Brawijaya. Kedua, Kelompok tani Sumber Mulyo yang berlokasi di dusun Kali Gayam, bekerja sama dengan LSM Internasioanal REI (Resource Exchange International) berhasil melahirkan produk manisan mangga podang yang telah menembus pasar luar negeri.

Tujuan utama pengembangan olahan mangga podang adalah meningkatkan pendapatan petani mangga podang dikarenakan harga produk mangga podang saat itu sangat rendah terutama pada saat panen raya sehingga perlu terobosan guna mendapatkan nilai tambah mangga podang. Setelah banyak produk olahan manga podang di pasaran, maka harga buah segar mangga podang pun ikut naik. Hal ini dikarenakan banyak buah mangga podang yang terserap sebagai bahan baku olahan mangga podang. Kalau dulu mangga podang hanya bisa dinikmati pada saat musim mangga, maka sekarang bisa dinikmati sepanjang tahun melalui olahan mangga podang.

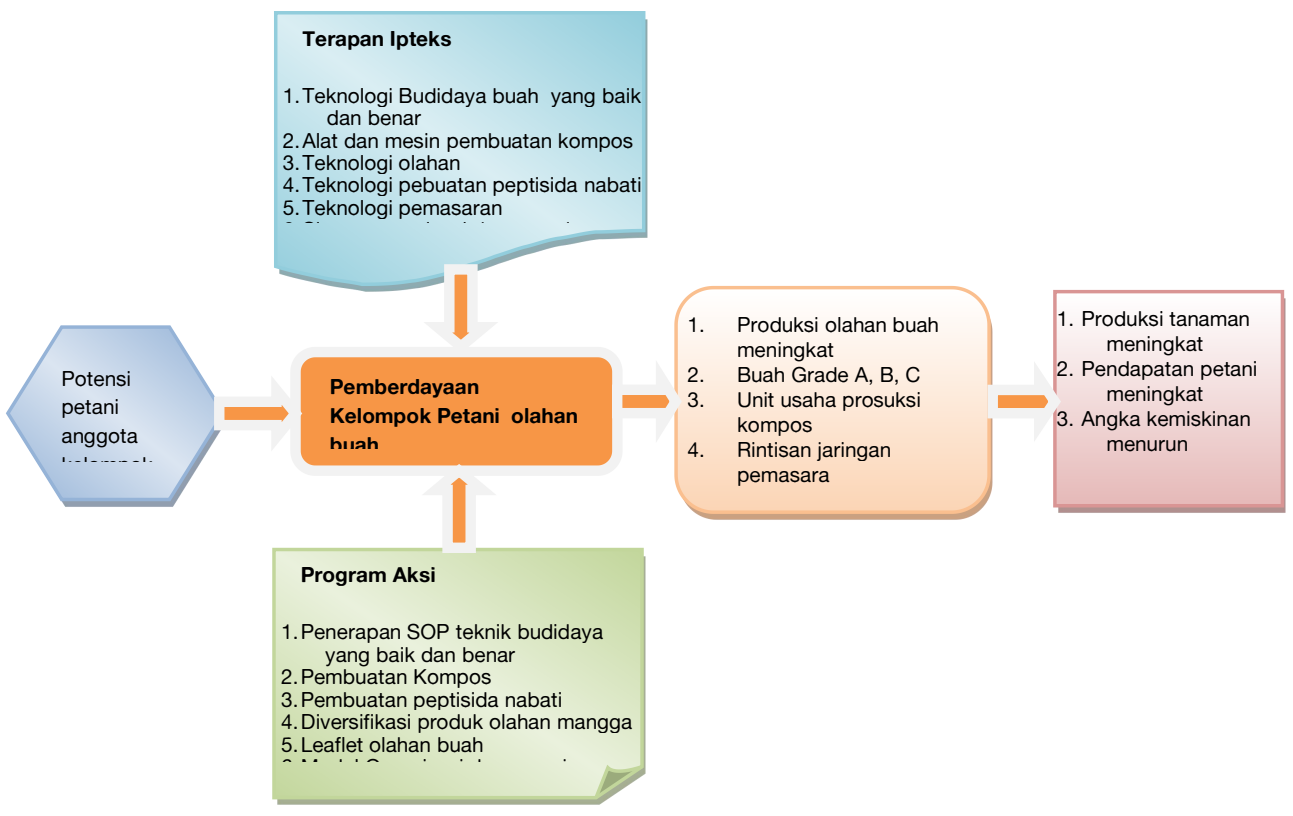

Gambar 2 Pemberdayaan Ekonomi Masyarakat Miskin Melalui Kelompok Produktif

2. Model Pemberdayaan Masyarakat Miskin Melalui kelompok Usaha Bersama Model kelompok usaha bersama yang dapat menjadikan masyarakat miskin keluar dari lingkaran kemiskinan sangat penting untuk dikaji. Mengingat sudah banyak upaya yang dilakukan sebelum ini dalam berbagai bentuk program pengentasan kemiskinan, namun belum banyak memberikan hasil sebagaimana yang diharapkan. Berbagai program telah dilakukan untuk mengentaskan kemiskinan. Namun adopsi sistem penanggulangan kemiskinan secara statis, melalui program kompensasi; bantuan langsung pangan, voucher pelayanan minimum kesehatan dan pendidikan, hanya dapat 
memecahkan persoalan kemiskinan jangka pendek (World Development Report, 2004). Mengingat ketika program telah berakhir, masyarakat miskin masih tetap memerlukannya. Kemudian program pengentasan kemiskinan dengan menggunakan kelompok sebagai media untuk mencapai tujuan dan sasaran program juga telah banyak dilakukan mulai dari tahun 1999, dimulai dari IDT, JPS, PDM-DKE, PEMP, LUEB, Inseminasi Buatan, PPK, P2KP, BSM, Raskin, Kur, Jamkesmas, KUR, PNPM Mandiri Pedesaan, Perkotaan dan lain-lain. Namun pengurangan angka kemiskinan tetap tidak beranjak dari angka 2 digit dan bahkan angka kemiskinan relatif cenderung meningkat. Hal ini terlihat dari tingkat kemiskinan yang masih tetap tinggi. Padahal dari hasil penelitian ini merujuk pada pentingnya peranan kelompok dalam pemberdayaan hampir seluruhnya merujuk bahwa kelompok merupakan salah satu alat yang dapat dijadikan sarana untuk mempercepat terjadinya proses pemberdayaan, terutama dalam pemberdayaan masyarakat miskin.

Sebagaimana halnya di wilayah Kecamatan Kandat, khususnya di Dusun Bulur merupakan salah satu dusun yang terkenal sebagai sentra usaha tahu dengan kualitas terbaik. Sebagai salah satu industri rumahan, usaha ini masuk dalam dalam kategori usaha kecil menengah yang tergabung dalam Kelompok Usaha Bersama (KUBE) binaan Dinas Sosial Kabupaten Kediri. Cara pembuatan tahu pun masih dengan cara tradisional,sehingga peran individu atau dalam hal ini para pekerja sangatlah besar dalam proses pembuatanya.

KUBE ini merupakan usaha kecil yang telah berdiri lebih dari 3 tahun yang bergerak di bidang pembuatan tahu putih berbahan dasar kedelai kualitas terbaik. Rata-rata produksi setiap hari menghabiskan 18 kilogram kedelai untuk sekali pemasakan sesuai kebutuhan normal. Disamping produksi tahu, kelompok ini juga berusaha untuk pengembangan produksi lainnya yaitu Susu Kedelei. Pemasaran dari susu kedelei ini juga berjalan lancar karena terkenal akan keenakan rasanya.

KUBE Bulur Jaya mendapatkan bantuan Rp. 30.000.000,- dari Kementrian sosial RI. dana tersebut di gunakan untuk pembelanjaan alat produksi, bahan baku dan kelengkapan lainya. Yang kendala adalah sulitanya mencari bahan baku. modal tetap menjadi kendala lanjutan dalam pengembangan usaha. Kesulitan dalam pemasaran dan persaingan usaha ketat. Kurangnya keterampilan teknis produksi dan keahlian Kurangnya pengetahuan dalam manajemen keuangan. Cara penyimpanan bila produksi tidak laku. Intensitas kunjungan pendamping yang kurang. Selain KUBE Bulur Jaya ada pula GTT (Gudang'e Tahu Takwa) merupakan pusat oleh-oleh khas kabupaten Kediri sebagai wadah untuk menampung dan memasarkan hasil-hasil UKM yang ada , serta menjadi lokasi tujuan wisatawan mencarioleh- oleh khas Kediri.

Tahu dan getuk pisang merupakan makanan khas dari Kabupaten Kediri. Usaha ini pula yang kini ditekuni oleh Gatot Siswanto, pemilik dari pusat oleh-oleh GTT. Berdiri sejak tahun 1993, awalnya Gatot hanya memiliki satu orang karyawan saja. Setelah mengikuti program pemerintah, yang diperuntukan bagi pemilik UKM (Usaha Kecil Menengah) tidak disia-siakan oleh Gatot. Mulai mendapat pembinaan pada tahun 2007, usaha GTT semakin berkembang, saat ini Gatot dibantu oleh 30 karyawan yang $90 \%$ berasal dari warga sekitar rumah produksi. Sehingga pemberdayakan warga menjadi meningkatkan perekonomian

KUBE "Muji Rahayu" adalah sebuah usaha kelompok yang bergerak dibidang produksi pengolahan biji blinjo menjadi emping blinjo, Asal mula terbentuknya KUBE ini karena adanya beberapa anggota PKH yang bekerja 
sebagai buruh tenaga dan pengolah kecil emping blinjo maka dari situlah dirintis untuk membuat kelompok usaha bersama. Dan untuk mempermudah akses permodalan dari pemerintah. Pada tahun 2008 terbentuklah KUBE "MUJI RAHAYU" dibawah pengawasan dinas sosial/masuk dalam binaan Program Keluarga harapan. Keanggotaan KUBE terdiri dari 10 an ggota Pada tahun 2010 KUBE ini mendapat bantuan dari Kementrian sosial RI berupa dana tunai sebesar Rp. 30 juta, untuk keperluan pengelolaan dan pengembangan usaha. Dalam perkembangannya KUBE ini dapat memperbanyak produksi emping blinjo dan juga bisa mengemas dengan label nama KUBE serta lebih cepat dalam pemasarannya. KUB lainnya binaan dari Badan Ketahanan pangan dan Penyuluhan Pertanian (BKP3) Kabupaten kediri adalah beternak itik. Beternak itik merupakan salah usaha yang mampu meningkatkan pendapatan sekaligus menciptakan peluang ekonomi, dan juga menciptakan lapangan pekerjaan didaerah tanpa menggantungkan hidup kepada pihak lain. Dengan menciptakan lapangan pekejaan sendiri maka dapat menyerap tenaga kerja warga daerah sekitar dan pengangguran didaerah akan berkurang.

Dari pembinaan dan pelatihan tentang beternak itik dengan cara dikandangkan ternyata hasilnya ebih efektif dan lebih bagus, dan juga cara untuk mengelola serta wawasan bagaimana itik yang produktif atau tidak. Setelah melihat peluang usaha ini semakin hari semakin maju warga Desa banyak beralih profesi sebagai peternak itik. Untuk mengembangkan usaha ini warga Desa terus diberikan pelatihan dan juga pembinaan agar warga yang berprofesi sebagai peternak dapat memiliki kemampuan untuk mengembangkan usahanya agar mampu memenuhi permintaan telur dan daging itik di pasar. Dengan berkembangnya peternak itik di Desa ini Akhirnya terbentuklah kelompok yang diberi nama Manunggal Lestari pada tanggal 22 Februari 2010 dengan 34 Anggota kelompok.

Selama ini kendalanya dalam beternak itik adalah kotoran itik baunya sangat menyengat dan mengganggu lingkungan sekitar. Kami mengharapkan bantuan dari dinas terkait untuk memberikan solusi dan bantuan misalnya dengan biogas. dengan adanya biogas kotoran-kotoran tersebut bisa dimanfaatkan untuk memasak dan juga untuk penerangan lampu

Model Kelompok Usaha Bersama (KUBE) dalam program pengentasan kemiskinan sangat penting untuk dikaji apakah program kelompok usaha bersama di Kabupaten Kediri benar-benar berdampak. Mengingat sudah banyak upaya yang dilakukan sebelum ini dalam berbagai bentuk program pemberdayaan kelompok usaha masyarakat miskin, namun masih belum banyak memberikan hasil. Padahal dari hasil studi yang merujuk pada pentingnya peranan kelompok dalam pemberdayaan hampir seluruhnya merujuk bahwa kelompok merupakan salah satu alat yang dapat dijadikan sarana untuk mempercepat terjadinya proses pemberdayaan, terutama dalam pemberdayaan masyarakat miskin. Namun tingkat kemiskinan masih tetap tinggi. Berdasarkan hal tersebut dengan menggunakan metode penelitian kualitatif dan kuantitatif dilakukan kajian pada program-program kemiskinan yang menggunakan model kelompok sebagai media sasaran dengan tujuan untuk merekonstruksi model kelompok usaha bersama (KUBE) masyarakat miskin yang tepat dalam Program pengentasan kemiskinan. Dari hasil penelitian diperoleh gambaran bahwan KUBE dibentuk karena adanya program bantuan yang akan diterima (Top-down) dan bukan berdasarkan keinginan masyarakat (bottom-up) untuk membentuk KUBE. 
Adapun tujuan Program Kelompok Usaha Bersama di Kabupaten Kediri adalah:

a) Meningkatkan pendapatan anggota KUBE masyarakat miskin

b) Meningkatkan kemampuan KUBE masyarakat miskin dalam mengakses berbagai pelayanan sosial dasar dan pasar, perbankan untuk memenuhi kebutuhan kehidupannya.

c) Meningkatkan kepedulian dan tanggung jawab sosial masyarakat dan dunia usaha dalam penanggulangan kemiskinan

d) Memperluas peluang dan kesempatan pelayanan kepada masyarakat miskin

Sedangkan pendekatan yang digunakan dalam Pelaksanaan Program Kelompok Usaha Bersama ada 3, yaitu:

a) Program Program Kelompok Usaha Bersama didasarkan pada pendekatan "Pembangunan Bertumpu Pada Kelompok" (community based development approach).

b) Pendekatan pada kelompok ini didasarkan atas dasar kesamaan tujuan, kesamaan kegiatan, kesamaan domisili, yang pada dasarnya mengarah pada efisiensi, efektivitas serta mendorong tumbuh dan berkembangnya capital social (modal sosial).

c) Kelompok Usaha Bersama (KUBE) bukan sebagai tujuan, tetapi sebagai wadah/organisasi dalam mengelola Usaha Ekonomi Produktif.

Program pemberdayaan masyarakat miskin diwadahi dalam bentuk KUBE, karena dengan sistem KUBE, kegiatan usaha yang tadinya dilakukan secara sendiri-sendiri kemudian dikembangkan dalam kelompok, sehingga akan memudahkan dalam pembinaan dan monitoring dan pembinaannya akan lebih efektif dan efisien baik dari segi pembiayaan, tenaga dan waktu yang digunakan. Dengan pembinaan melalui kelompok KUBE, maka diharapkan kelompok ini akan saling membantu satu sama lain antara yang lemah dengan yang lebih mampu, baik dalam kemampuan, keterampilan, modal dan lain-lain yang terkait dengan kegiatan-kegiatan KUBE. Diharapkan dengan KUBE, dapat menumbuhkan rasa kebersamaan, kekeluargaan, kegotongroyongan, rasa kepedulian dan kesetiakawanan sosial, baik di antara keluarga binaan sosial maupun kepada masyarakat secara luas karena mereka hidup dalam kelompok.

Tujuan KUBE:

a) Meningkatkan kemampuan anggota KUBE di dalam memenuhi kebutuhan-kebutuhan hidup sehari-hari, ditandai dengan: meningkatnya pendapatan keluarga; meningkatnya kualitas pangan, sandang, papan, kesehatan, tingkat pendidikan

b) Meningkatnya kemampuan anggota KUBE dalam mengatasi masalahmasalah yang mungkin terjadi dalam keluarganya maupun dengan lingkungan sosialnya,

c) Meningkatnya kemampuan anggota KUBE dalam menampilkan perananperanan sosialnya, baik dalam keluarga maupun lingkungan sosialnya.

3. Model Pembaerdayaan Masyarakat Miskin Berbasis Kewilayahan

1. Pemberdayaan Masyarakat Miskin Berbasis Potensi Desa

Permasalahan yang dihadapi oleh Pemerintah daerah saat ini dalam upaya meningkatkan kesejahteraan masyarakat miskin Program-program Penanggulangan dan pengentasan kemiskinan berbasis potensi desa di 
dimaksudkan untuk meningkatkan dan mengembangkan peran masyarakat serta fungsi lembaga-lembaga desa, untuk mendorong kesadaran kaum miskin dalam memperbaiki nasibnya. Sehingga, berbagai upaya penanggulangan dan pengentasan kemiskinan harus memberikan kontribusi pada peningkatan kemampuan masyarakat miskin. Ada 2 (dua) cara yang dapat dilakukan untuk penanggulangan dan pengentasan kemiskinan ini, yakni: (i) mengurangi beban biaya bagi Rumah Tangga Sangat Miskin, seperti misalnya: biaya pendidikan, biaya kesehatan, infrastruktur seperti air bersih, jalan desa dan sebagainya, (ii) meningkatkan pendapatan Rumah Tangga Miskin dan Hampir Miskin dengan jalan antara lain pelatihan ekonomi produktif, usaha ekonomi, stimulan modal kerja/ usaha, pasar desa, dan kegiatan pemberdayaan ekonomi lokal serta peningkatan produksi melalui Teknologi Tepat Guna.

Program Pemberdayaan Potensi Desa ini dimaksudkan sebagai upaya untuk mengembangkan potensi ekonomi unggulan desa dengan pemberdayaan Rumah Tangga Miskin. Disamping itu, melalui Pemberdayaan Potensi Desa diharapkan mampu mewujudkan pengelolaan program penanggulangan kemiskinan secara profesional dan berkelanjutan dengan berbasis pada potensi dan modal sosial lokal sehingga dapat mengembangkan pola-pola baru yang inovatif untuk penanggulangan kemiskinan.

Pemberdayaan Potensi Desa dikelola secara terpadu dengan membuka ruang partisipasi antar stakeholders dalam rangka memfasilitasi pemberdayaan RTM maupun pengembangan potensi ekonomi unggulan desa. Dalam implementasinya, peran serta Perguruan Tinggi (PT) yang memiliki reputasi keahlian dan pengalaman dibidang pemberdayaan masyarakat maupun pengembangan ekonomi lokal sangat diperlukan. Perguruan Tinggi (PT) diharapkan mampu berperan sebagai fasilitator dan mediator bagi pengembangan akses dan kerjasama maupun mampu mengembangkan potensi desa.

Program Pemberdayaan Potensi Desa disusun sebagai acuan dasar bagi pengelola program maupun stakeholders lainnya agar mampu mengelola program secara optimal maupun mengembangkan peran-peran fasilitasi secara tepat guna mendukung pengembangan potensi ekonomi unggulan desa dan pemberdayaan Rumah Tangga Miskin (RTM).

Tujuan Umum

Mendorong terwujudnya kemandirian masyarakat desa melalui Pengembangan Potensi Unggulan dan Penguatan Kelembagaan serta Pemberdayaan Kelompok Masyarakat (Pokmas) RTM

Tujuan Khusus

1. Meningkatkan peran aktif masyarakat dalam pengambilan keputusan pembangunan secara terbuka, demokratis dan bertanggung jawab;

2. Mengembangkan kemampuan usaha dan peluang berusaha demi peningkatan pendapatan dan kesejahteraan Rumah Tangga Miskin.

3. Membentuk dan mengoptimalkan fungsi dan peran Unit Pengelola Keuangan dan Usaha (UPKu) sebagai Lembaga Pemberdayaan Ekonomi Masyarakat.

4. Membentuk, memfasilitasi dan memberikan pembinaan Pokmas UEP terutama pada aspek kelembagaan dan pengembangan usaha.

5. Mengembangkan potensi ekonomi unggulan desa yang disesuaikan dengan karateristik tipologi desa.

6. Mendorong terwujudnya keterpaduan peran dan kemitraan antar SKPD maupun stakeholders lainnya sebagai pelaku dan fasilitator program. 
Ruang Lingkup Program meliputi:

1. Pengembangan Potensi Ekonomi Unggulan Desa.

a. Pengembangan Potensi ekonomi unggulan Desa disesuaikan dengan karakteristik tipologi desa dengan fokus kegiatan antara lain meliputi:

b.Pengkajian dan fasilitasi pengembangan potensi dan produk unggulan Desa yang mampu mendukung pemberdayaan RTM;

c. Peningkatan Sumber Daya manusia dan Kemampuan Kewirausahaan;

d.Pengembangan dukungan sarana dan prasarana produksi/budidaya/ usaha jasa;

e. Pengembangan Teknologi Tepat Guna untuk Pengolahan dan Pemasaran Hasil;

f. Pengembangan kelembagaan dan manajemen usaha;

g. Penguatan permodalan;

h.Pengembangan akses informasi dan promosi produk, serta kegiatan lainnya sesuai kebutuhan pengembangan potensi desa.

2. Pengembangan sinergi peran SKPD serta stakeholders lainnya dalam memfasilitasi Pemberdayaan Potensi Desa.

3. Pendampingan, Pendampingan oleh Perguruan Tinggi yang secara operasional di lokasi dilaksanakan oleh Tenaga Pendamping Masyarakat (TPM) dengan dukungan dan arahan Tenaga Ahli. Pendampingan TPM diorientasikan untuk memfasilitasi proses kegiatan sesuai dengan tahapan. Pendampingan Tenaga Ahli diorientasikan untuk memfasilitasi pengembangan potensi ekonomi unggulan Desa.

4. Pengembangan lanjutan oleh Perguruan Tinggi Pendamping dalam bentuk kegiatan pemberian jasa konsultansi, mengalokasikan kegiatan dosen dan atau mahasiswa untuk memfasilitasi kegiatan yang relevan dengan pengembangan potensi Desa, serta memanfaatkan Desa lokasi sebagai laboratoriam lapang bagi perguruan tinggi pendamping;

Ruang Lingkup Kegiatan meliputi:

1. Tahun Pertama, kegiatan Tahun Pertama meliputi :

a. Pengembangan Potensi Unggulan Desa;

b. Pengembangan Sumber Daya Manusia (SDM);

c. Pengembangan Sarana Prasarana RTS.

2. Tahun Kedua, kegiatan Tahun Kedua difokuskan pada:

a. Penguatan modal UPKu, yang dapat diperoleh dari APBD/APBN, Perguruan Tinggi Pendamping dan sumber-sumber lainnya yang sah.

b. Peningkatan kualitas dan kuantitas Pokmas (RTM) dalam pengelolaan usaha.

c. Pengembangan kemitraan SKPD serta stakeholders lainnya untuk mendukung pengembangan potensi ekonomi unggulan Desa.

d. Pendampingan penguatan, yang bersinergi dengan Perguruan Tinggi Pendamping.

3. Tahun Ketiga, kegiatan Tahun Ketiga difokuskan pada pemandirian Desa yang difasilitasi oleh Pemerintah Kabupaten Kediri.

a) Pemberdayaan Masyarakat Miskin Berbasis Ketahanan Pangan

Untuk mencegah kemiskinan ini Pemerintah telah mengeluarkan kebijakan mengenai penanggulangan kemiskinan. Perarutan Presiden Nomor 13 Tahun 2009 tentang Koordinasi Penanggulangan Kemiskinan menyatakan bahwa (1) penanggulangan kemiskinan adalah kebijakan dan program pemerintah pusat dan daerah yang dilakukan secara sistematis, terencana, dan bersinergi dengan dunia usaha dan masyarakat untuk mengurangi jumlah penduduk miskin dalam rangka meningkatkan derajat kesejahteraan rakyat; dan (2) 
program penanggulangan kemiskinan adalah kegiatan yang dilakukan oleh pemerintah pusat dan daerah, dunia usaha, serta masyarakat untuk meningkatkan kesejahteraan masyarakat miskin, serta pemberdayaan usaha ekonomi mikro dan kecil.

Kementerian Pertanian melalui Badan Ketahanan Pangan telah meluncurkan program pencegahan kemiskinan ini melalui kegiatan Pengembangan Desa Mandiri Pangan (Demapan) sejak tahun 2006. Demapan adalah desa/kelurahan yang masyarakatnya mempunyai kemampuan untuk mewujudkan ketahanan pangan dan gizi melalui pengembangan subsistem ketersediaan, subsistem distribusi, dan subsistem konsumsi pangan dengan memanfaatkan sumberdaya setempat secara berkelanjutan. Tujuan kegiatan Demapan memberdayakan masyarakat miskin/rawan pangan menjadi kaum mandiri untuk mengurangi kemiskinan dan mewujudkan ketahanan pangan dan gizi.

Pelaksanaan Kegiatan Demapan dilaksanakan dalam 4 (empat) tahap selama 4 (empat) tahun:

1. Tahap Persiapan (tahun I) berfokus pada penyiapan database, penguatan kelembagaan masyarakat dan layanan modal;

2. Tahap Penumbuhan (tahun II) berfokus pada pengembangan usaha kelompok;

3. Tahap Pengembangan (tahun III) berfokus pada peningkatan sarana prasarana;

4. Tahap Kemandirian (tahun IV) berfokus pada peningkatan kesehatan dan gizi.

Pendekatan Pengembangan Demapan

Pelaksanaan kegiatan Demapan, melalui: (1) pemberdayaan masyarakat miskin, (2) penguatan kelembagaan masyarakat dan pemerintah desa, (3) pengembangan sistem ketahanan pangan, dan (4) peningkatan koordinasi lintas sektor untuk mendukung pembangunan dan pengembangan sarana dan prasarana pedesaan.

Proses pemberdayaan masyarakat dilakukan melalui: (1) pelatihan; (2) pendampingan; dan (3) peningkatan akses untuk pengembangan kerja sama partisipasi inklusif, peningkatan kapasitas individu dan kelembagaan masyarakat, perubahan sosial dan ekonomi yang lebih baik, serta peningkatan ketahanan pangan. Pemberdayaan ditujukan untuk rumahtangga sasaran (rumahtangga miskin khususnya) dan kelembagaan masyarakat di pedesaan. Melalui upaya ini diharapkan terjadi perubahan dinamika masyarakat dalam perencanaan dan berkelompok untuk menanggulangi kerawanan pangan di desanya yang difasilitasi oleh pendamping, lembaga layanan modal dan lembaga layanan masyarakat secara berkesinambungan dalam rangka penguatan modal dan sosial.

Fasilitasi pemerintah melalui pendampingan dan bantuan sosial (bansos), diharapkan mampu mengoptimalkan input: sumber daya alam, sumber daya manusia, dana, teknologi, dan kearifan lokal untuk menggerakan sistem ketahanan pangan, dari aspek (1) subsistem ketersediaan pangan dalam peningkatan produksi dan cadangan pangan masyarakat; (2) subsistem distribusi yang menjamin kemudahan akses fisik, peningkatan daya beli, serta menjamin stabilisasi pasokan; dan (3) subsistem konsumsi untuk peningkatan kualitas pangan dan pengembangan diversifikasi pangan. Bansos yang disalurkan kepada masyarakat dikelola oleh LKD yang berfungsi sebagai layanan modal; lembaga layanan kesehatan/posyandu bersama kader gizi dan PKK mampu menggerakkan masyarakat dalam merubah mind set atau pola pikir tentang pentingnya ketahanan pangan tingkat rumah tangga. 
Hasil evaluasi pelaksanaan Demapan pada tahun 2012 ternyata dari 1.516 desa yang telah ditumbuhkan yang tersebar di 33 provinsi dan 410 kabupaten/kota. 359 desa diantaranya telah memasuki tahap exit strategy (telah dilepas), 466 desa telah memasukkin tahap kemandirian, 262 desa berada tahap pengembangan dan 429 desa pada tahap berada penumbuhan. Indikator kerberhasilan desa yang dikategorikan exit strategi apabila masyarakatnya telah sejahtera, ketersediaan pangan telah terpenuhi, distribusi pangan lancar dan mereka telah mengkonsumsi pangan yang beragam bergizi seimbang dan aman, serta telah mempunyai usaha yang produktif. Bagi desa yang telah memasukki exit strategi kepada para penyuluh atau petugas tingkat lapangan diharapkan tetap membinanya serta mencarikan fasilitas-fasilitas atau peluang lain yang dapat mengembangkan usahanya lebih lanjut dengan menghubungi dinas/instansi terkait.

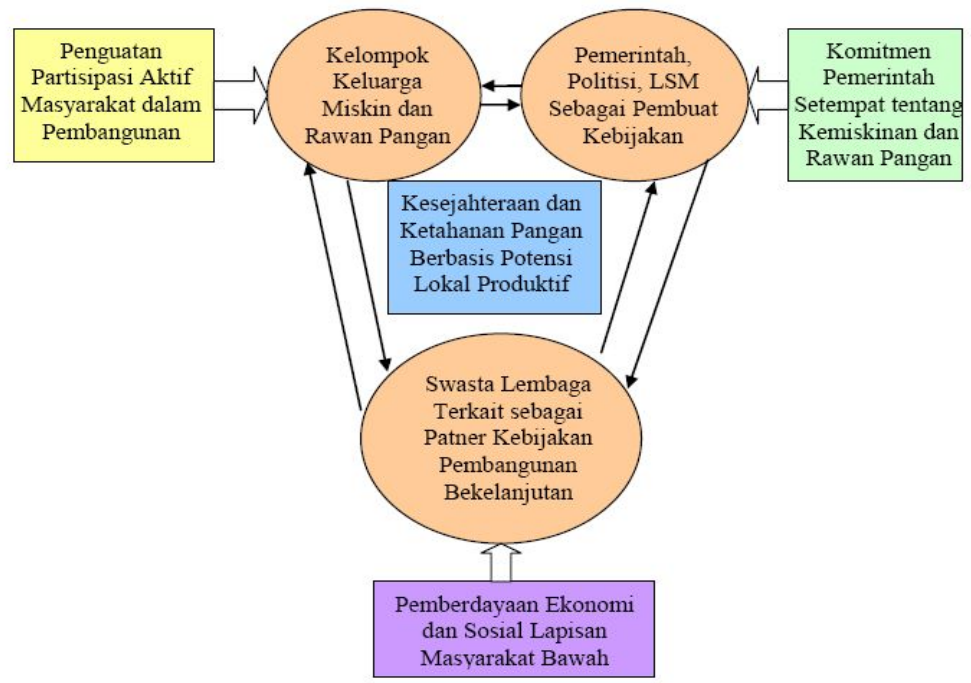

Gambar 3 Pemberdayaan Ekonomi Masyarakat Miskin Berbasis Ketahanan Pangan

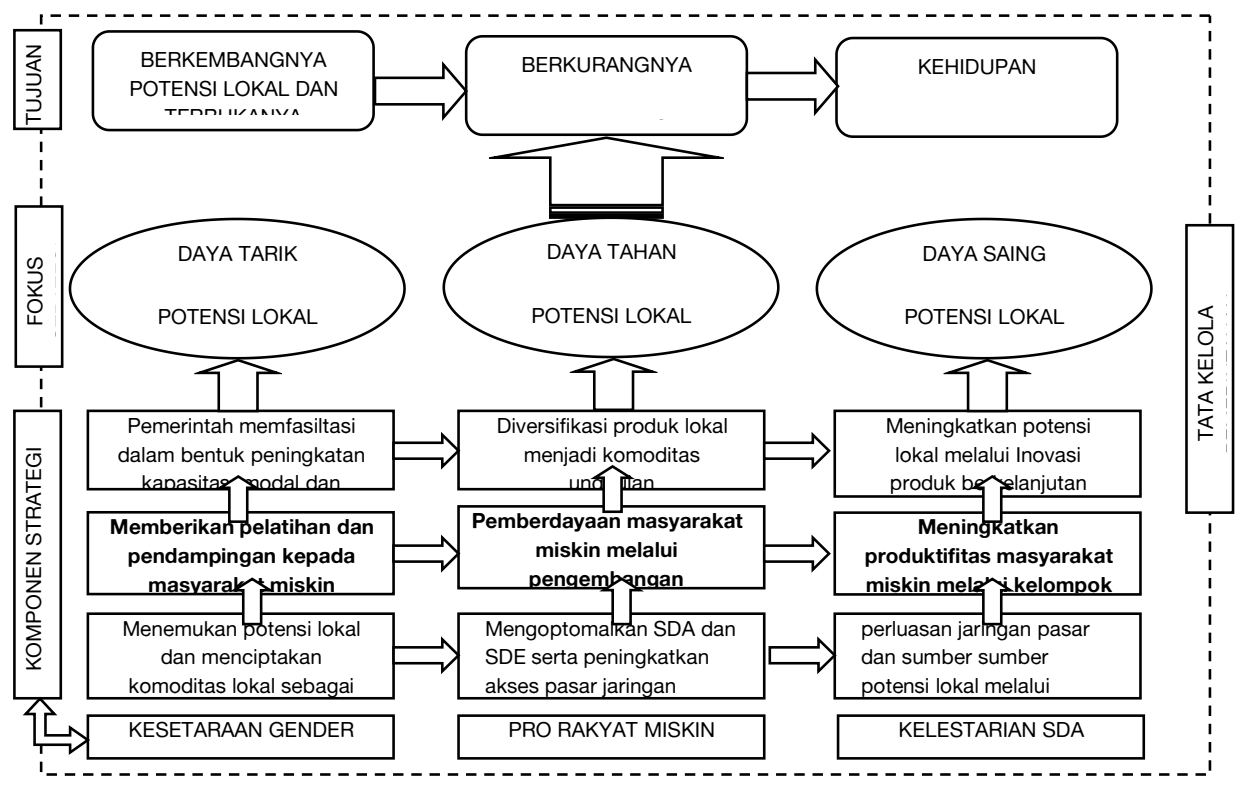




\section{Gambar 4 Model Pemberdayaan Ekonomi Masyarakat Miskin Melalui Pengembangan Ekonomi Lokal}

\section{Kesimpulan dan Saran}

A. Kesimpulan

1. Prioritas yang utama dari kabupaten kediri adalah pada sektor Pertanian, Perkebunan, Peternakan dan Perikanan kemudian pada sektor berikutnya adalah Perdagangan, Hotel \& Restoran dan sektor prioritas selanjutnya adalah bidang industri dan Jasajasa.

2. Sentra penghasil mangga podang di Kabupaten Kediri terdapat di lima kecamatan yang melingkari gunung Wilis yaitu Kecamatan Banyakan, Tarokan, Grogol, Mojo, dan Semen. Jumlah mangga Podang terbesar berada di Kecamatan Banyakan dan Tarokan dengan jumlah kurang lebih 15 ribu pohon. Rata-rata hasil panen perpohon $20-40 \mathrm{~kg}$ maka potensi total panen mangga podang bisa mencapai 600 ton permusim.

3. Kelompok Wanita Tani 'Budidaya' yang berlokasi di dusun Sumberbendo, telah mendirikan industri rumah tangga olahan mangga podang bekerjasama dengan JICA (Japan International Cooperation Agency: Lembaga pendanaan dari Pemerintah Jepang), Dinas Pertanian Kabupaten Kediri, dan Universitas Brawijaya.

4. Kelompok tani Sumber Mulyo yang berlokasi di dusun Kali Gayam, bekerja sama dengan LSM Internasioanal REI (Resource Exchange International) berhasil melahirkan produk manisan mangga podang yang telah menembus pasar luar negeri.

5. Tujuan utama pengembangan olahan mangga podang adalah meningkatkan pendapatan petani mangga podang dikarenakan harga produk mangga podang saat itu sangat rendah terutama pada saat panen raya sehingga perlu terobosan guna mendapatkan nilai tambah mangga podang. Setelah banyak produk olahan manga podang di pasaran, maka harga buah segar mangga podang pun ikut naik. Hal ini dikarenakan banyak buah mangga podang yang terserap sebagai bahan baku olahan mangga podang. Kalau dulu mangga podang hanya bisa dinikmati pada saat musim mangga, maka sekarang bisa dinikmati sepanjang tahun melalui olahan mangga podang.

6. Dusun Bulur, Kecamatan Kandat, merupakan salah satu dusun yang terkenal sebagai sentra usaha tahu dengan kualitas terbaik. Sebagai salah satu industri rumahan, usaha ini masuk dalam dalam kategori usaha kecil menengah yang tergabung dalam Kelompok Usaha Bersama (KUBE) binaan Dinas Sosial Kabupaten Kediri. Cara pembuatan tahu pun masih dengan cara tradisional,sehingga peran individu atau dalam hal ini para pekerja sangatlah besar dalam proses pembuatanya.

B. Saran

1. Untuk dapat meningkatkan kondisi sosial ekonomi masyarakat miskin Kabupaten Kediri yang bergerak pada sektor-sektor industri berbasis potensi lokal, perlu adanya inisiasi program yang terarah dan berkelanjutan. Hal ini perlu diawali dengan pendataan para pelaku usaha agar menghasilkan database para pelaku industri 
berbasis potensi lokal, sehingga inisiasi program yang tepat guna, tepat sasaran dan berkelanjutan dapat dijalankan berdasarkan kebutuhan para pelaku usaha.

2. Sarana dan prasarana pendukung perlu terus mendapatkan perhatian dari pemerintah daerah. Termasuk pula ketersediaan sarana penunjang kegiatan wisata yang dapat mendukung kegiatan ekonomi masyarakat miskin berbasis potensi lokal di Kabupaten Kediri.

3. Untuk dapat meningkatkan efektivitas pemberdayaan ekonomi masyarakat miskin berbasis potensi lokal di Kabupaten Kediri, baik dari bantuan berupa bimbingan teknis, permodalan, bantuan alat produksi dan sebagainya, perlu diawali dengan pendataan para pelaku usaha. Hal ini dapat dilakukan secara kerjasama oleh pihak kelurahan dengan Dinas Koperasi \& UMKM maupun Dinas Perindustrian \& Perdagangan. Sehingga dengan demikian tidak akan terjadi lagi program yang diberikan tidak sesuai dengan kebutuhan masyarakat, serta tidak terjadi lagi ada masyarakat penerima bantuan yang double funding.

\section{Daftar Pustaka}

Astuti dan Haryanto. 2005. Ekonomi Regional: Teori dan Aplikasi, Edisi Revisi. Medan: Bumi Aksara.

Azis, Iwan Jaya. 1994. Ilmu Ekonomi Regional dan Beberapa Aplikasinya di Indonesia. LPFE UI. Jakarta.

Baswir, Revrisond. 1999. Pembangunan pedesaan dan penanggulangan kemiskinan. Dalam Pembangunan Ekonomi Rakyat di Pedesaan Sebagai Strategi Penanggulangan Kemiskinan (Penyunting Hasan Basri), Cetakan Pertama, hal 72-82. Bina Rena Pariwara, Jakarta.

Bratakusumah, Deddy Supriady \& Riyadi. 2005. Perencanaan Pembangunan Daerah. Jakarta: PT. Gramedia Pustaka Utama.

Fei, J.C.H \& Gustav, R. 1964. Development Economics: What Next? Dalam Kuncoro, Mudrajad. Otonomi dan Pembangunan Daerah. Penerbit Erlangga. 2004.

Kuncoro, Mudrajat. 2004. Otonomi dan Pembangunan Daerah, Erlangga, Jakarta.

Mawardi, M. J. 2007. Peranan Social Capital Dalam Pemberdayaan Masyarakat. Komunitas, Jurnal Pengembangan Masyarakat Islam. Vol. 3 No. 2, 5 - 14.

Meier, Gerald M. 1989. Leading Issues in Economic Development. Oxford University Press, Cambridge.

Mellor, John W. 1976, The New Economics of Growth: A Strategy for India and the Developing Word, dalam Sadono Sukirno, 1985, Ekonomi Pembangunan, FE-UI, Jakarta.

Nurkse, R. 1953. Problems of Capital Formation in Underdeveloped Countries. Oxford Basis Blackwell.

Priyambada, A, A., Suryahadi., dan S, Sumarto., 2002. "What Happened To Child Labor In Indonesia During The Economic Crisis; The Trade-Of Between School And Work". SEMERU Working Paper. Jakarta.

Rintuh, Cornelius dan Miar. 2005. Kelembagaan dan Ekonomi Rakyat.Yokyakarta: BPFEYokyakarta.

Sharp dan Ansel M. 1996. Economics of Social Iissues, edisi ke 12, Richard D. Irwin, Chicago, bab VII.

Sumodiningrat, Gunawan. 2002. Pemberdayaan Masyarakat dan Jaringan Pengaman Sosial, Jakrta: PT Gramedia Pustaka Utama.

Sumodiningrat, Gunawan. 2002. Strategi pemberdayaan masyarakat dalam penanggulangan kemiskinan. Materi kuliah umum Program Pasca Sarjana Universitas Brawijaya, Malang. 